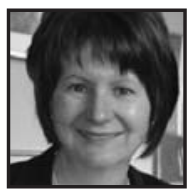

\title{
The Master Teacher Program: Professional Development for College Teachers
}

\author{
Susan Kerwin-Boudreau, Champlain College
}

\section{ABSTRACT (Press Here for Sound)}

In this qualitative study ${ }^{1}$ I explored six college (CEGEP) teachers' perspectives on teaching and learning over a two-year period, as they completed the first four courses in a professional development program, the Master Teacher Program (MTP). Repeated, semi-structured interviews were analyzed, using the complementary processes of categorizing and connecting. Results revealed, through four patterns and three major dimensions, a process of evolution from a teacher- to a learner-centered perspective.

\section{Situating Myself}

am a teacher in the Quebec CEGEP system. CEGEP is an acronym for Collège d'enseignement général et professionnel, or College of General and Vocational Education. Launched in 1967 and exclusive to the province of Quebec, Canada, the CEGEP represents the first stage of postsecondary, higher education. Students can enroll in either a pre-university program that leads to university studies, or a technical career program that prepares them for the job market. All CEGEP students take a core of common, general education courses.

The impetus for me to begin this research in 2002 originated with some questions I had concerning my own practice. I had been teaching psychology at the CEGEP level for almost 30 years. While I enjoyed teaching my discipline and received favorable feedback on student evaluations, my knowledge of pedagogy was founded on years of accumulated classroom experience. Essentially, this amounted to a privatized, trial-and-error self-assessment of my teaching, which was largely based on my 
own experiences as a learner. My practice was neither particularly reflective, nor was it informed by current findings in the field of education. Through my involvement as a course consultant in a professional development program for CEGEP teachers, the Master Teacher Program (MTP), I began to explore the educational literature on teaching. This led me to embark on doctoral studies in order to further investigate the two domains of professional development and reflection in higher education, and to reflect on this knowledge, in light of my own practice.

\section{Review of the Literature and Research Question}

Decades of research have established clear links between the quality of teaching and student learning outcomes. However, much of this research has focused on primary and secondary teacher education, where the emphasis is placed on pedagogy. The situation is different in higher education, where teachers are disciplinary experts, and, in spite of a lack of grounding in pedagogy, they are expected to be able to teach effectively. Beaty (1998) has referred to this assumption as double professionalism. According to the author, current research suggests that expertise in how to teach is as important as expertise in one's discipline.

Over the past few decades, teaching has assumed an increasingly central role in higher education. The heightened status of teaching has been fueled by developments such as Boyer's (1987) Scholarship of Teaching movement, and by the changing landscape in higher education (Nicholls, 2001), that is, the increase in student numbers and diversity. Factors such as these have led to demands for greater accountability in the areas of both teaching and student learning. In spite of these demands, the fact remains that the idea of learning to teach in higher education is a relatively recent phenomenon that has met with considerable resistance (Brew, 1999). Knapper (2005) maintains that this resistance can be linked to a lack of formal preparation for learning to teach in higher education, the absence of accreditation for minimum levels of competence, and the lack of faculty involvement in continuous professional development. New teachers are particularly vulnerable. Emerging from disciplinary-specific, research-oriented training in graduate school and faced with an overwhelming teaching load, they resort to survival mode in their teaching. The combination of these factors does not foster teaching practices that develop complex levels of thinking in students (Saroyan \& Amusden, 2004). 
Colleges and universities have responded to the challenge to improve teaching by offering support for faculty that ranges from workshops to courses to longer-term programs. Many of these initiatives have been critiqued for not meeting teachers' needs. These needs include the fact that learning to teach is a process that evolves over time and is enhanced through interactions with competent peers. As well, such professional development initiatives need to be embedded in relevant theory and research, so that teachers can establish clear links from theory to practice and from practice to theory (cited in Sprinthall, Reiman, \& Thies-Sprinthall, 1996). Programs that integrate these criteria need to be developed, implemented, and evaluated.

One area of particular importance that underlies the process of teacher development concerns faculty perspectives or beliefs about teaching and learning. These perspectives are based on complex influences that include one's experiences as a learner, and often operate at an unconscious level (Kember, 1997). Perspectives act as filters and play a critical role in decisions that teachers make (Saroyan et al., 2004). According to Kember, efforts that focus on changing teachers' approaches or teaching new skills without examining and reorienting perspectives will be shortlived. Others, including Kember and Kwan (2002), McAlpine and Weston (2000), and Hativa (2002) have also concluded that in order to improve the quality of teaching in higher education, teachers' underlying perspectives about the nature of teaching and learning must be addressed. At the pre-college level, a significant body of research on teacher perspectives exists. In contrast, at the college level, very few studies have been conducted into how these perspectives might influence teaching practice (Fang, 1996). Hence, this has emerged as an important area of investigation.

A number of theoretical frameworks can shed light on the process of change in teacher perspectives in higher education. Prominent among these are Ramsden's (1992) theory of teacher thinking and Mezirow's (1981) theory of transformative learning. As well, several researchers including Kember (1997), Kember and Kwan (2002), and Samuelowicz and Bain (2001) have described a progression in teacher perspectives from a teacher-centered to a learner-centered orientation. However, many studies have arrived at this continuum as a result of conducting single interviews with several teachers. For example, Samuelowicz and Bain outline the framework that they derived from single interviews, each lasting from 1-1.5 hours, with several faculty members. According to the authors, the categories that emerged were "as far as possible ... based upon the transcripts rather than our preconceptions" (p.304).What is missing is a description of the underlying process that individual teachers might experience, as their perspectives shift from teacher- to learner-centeredness. 
If and when this shift happens, it often occurs when teachers are exposed to pedagogical knowledge that challenges their underlying beliefs about teaching and learning. According to Kember, there are few documented attempts to promote conceptual change among teachers in higher education, since such endeavors require a sustained effort over time. Therefore, it is important to examine the process of evolving perspectives that might occur within individual teachers over time, as their beliefs are challenged, and if necessary, reoriented. Further, the amount of time it takes to bring about this change in perspectives needs to be explored.

In this study I examined college teachers' perspectives over time, as they were enrolled in a professional development program, the Master Teacher Program (MTP). The overarching question that guided my research was, "How does reflecting on teaching and learning throughout the first four courses which cover a two-year period in a professional development program (MTP) contribute (or not) to teachers' changing perspectives on teaching and learning?"

\section{The Master Teacher Program}

The MTP is a professional development program tailored specifically for Anglophone college teachers within the Quebec CEGEP system. The program is unique in that its curriculum has been designed and is taught by well-reputed CEGEP teachers, many of whom have been instrumental in building the college system (Bateman, 2002). From its outset, the MTP has sought to embody a sense of mutual ownership. A Consortium of Anglophone CEGEPs was established to oversee the program. A steering committee, composed of local representatives from member CEGEPs was created, and meets regularly to administer the MTP. Affiliated with the Performa Program at the University of Sherbrooke in Quebec, participants can earn either a Diploma in Education (D.E.) after accumulating 30 credits or a Master's in Education (M.Ed) after 45 credits. Over the past several years close to 300 participants have registered in the program and taken at least one course. Currently over 140 students are pursuing course work. As well, a number of students have completed the D.E. and the M.Ed.

The MTP seeks to promote the scholarship of teaching by providing CEGEP teachers with the requisite knowledge, competencies, and personal qualities that effective teaching at this level requires. In particular, the program aims to "develop in each new teacher the ability to simultaneously observe, monitor, analyze, and adjust 
when necessary the complex intellectual, psychological and emotional processes that occur in their respective classrooms" (Bateman, 2002, p. 2 of 6). In offering direct and practical assistance to new teachers, it aspires to shorten the time it takes to evolve from a novice to a master teacher (Bateman).The MTP's strong academic component is based on contemporary theorizing about how people learn (Bransford, Brown, Cocking, \& Donovan, 2000), and in particular, how adults learn (Mezirow, 1992).

The first four courses form the core of this program. These courses include College Teaching: Issues and Challenges, Psychology of Learning for the College Classroom, Instructional Strategies, and Assessment. These courses are compulsory for all students and are usually taken in a sequential fashion. Through these courses, teachers are encouraged to reflect on their perspectives on teaching and learning, and to reconsider these, in light of current findings from cognitive science. In this study I tracked teachers' perspectives on teaching and learning as they completed these four core courses.

\section{Methodology}

The cohort that I selected to study began the MTP in the fall of 2005. Six female teachers agreed to participate in the research. They were from a number of CEGEPs, with teaching experience ranging from one to twenty-five years in a variety of disciplines. They taught in both pre-university and professional programs. To ensure anonymity, each participant was given a pseudonym from A through F (Anne, Barb, Carly, Deana, Ella and Fran).I interviewed each participant after she completed each of the first four courses in the MTP, and a fifth time for a retrospective interview. In addition to collecting a total of 25 hours of interviews with the six participants, they also sent me their concept maps and journals. I used their reflections from these three sources that covered a two-year period to assess their perspectives on teaching and learning over time.

In this qualitative study, I applied the dual processes of categorizing and connecting to analyze the data (Maxwell \& Miller, 2008). When used together, these two procedures can provide a more holistic understanding of the results. To categorize the data I used the constant comparative method as outlined by Maykut and Morehouse (1994) and by Charmaz (1998; 2000; 2005). Over a period of approximately 15 months, I manually coded every line of 418 pages of transcribed interview data. I also examined other sources including two sets of the participants' concept 
maps on effective teaching, and approximately 360 pages of their reflective journals. I did not code the concept maps and reflective journals but rather used these materials as evidence to corroborate the findings from the interview data. After categorizing the interview data, I used a connecting strategy to construct three narrative summaries that were based on a more contextualized analysis of each participant's story. The three participants that I selected for the narratives differed in terms of years of teaching experience, disciplinary background, and type of program. Therefore, they represented a purposive sample. I applied a methodology known as holistic content analysis as outlined by Lieblich (1998) and Seidman (1998) to identify major themes for the summaries. I also used a technique known as ghostwriting (Rhodes, 2000), whereby I constructed the narratives in the first person, using the participant's own words as much as possible. I sent the stories to the participants for their feedback; therefore the narratives became jointly constructed products. Throughout the process of data collection, analysis, and interpretation I wrote analytic memos. These memos helped me to remain aware of my biases, as well as the particular lenses, including that of researcher/teacher, through which the data were filtered.

\section{Results}

In this section I describe the findings that emerged as a result of categorizing and connecting the data. Through categorizing, four major patterns became apparent. The process of connecting the data revealed more contextualized themes. Findings from these two methods converged into three major dimensions. Reflection on practice proved to be the principal mechanism underlying changes in the participants' perspectives on teaching and learning. These results are elaborated in the following section.

\section{Four Patterns}

\section{Categorizing the Data}

The process of evolution in the six participants' perspectives on teaching and learning over two years was revealed through four major patterns or phases. These patterns became apparent as a result of coding the interview data. As I examined the categories that emerged I asked myself, "What does this remind me of?" The images that resulted provided me with a way of clustering the categories, and 
allowed me to view the data, at increasingly abstract levels. I used a metaphorical term to represent these images. The metaphors of awakening, stretching, exercising, and shaping provided a new lens onto the data (Lakoff \& Johnson, 2003). As thematic pieces of a process, the particular kinesthetic and emotional qualities that these metaphors evoked allowed me to view the phases in a qualitatively different, more integrated fashion.

When I analyzed the first set of interviews, three major themes emerged. First, the participants had become aware of their original perspectives on teaching and learning, which placed the teacher in a central role. They were also becoming unsettled, as they encountered evidence that challenged these perspectives, and they slowly began to shift their thinking. For some teachers, the process of becoming unsettled had begun even before the MTP, and had served as an impetus for them to seek professional assistance. Deana, a new teacher, was plagued by student failure:"I remember my first semester. I was well prepared; I thought I was doing everything a teacher should be doing. But the students were not learning."

Fran, an experienced teacher, was seeking a sense of community:

I was feeling quite alone in the classroom. I was feeling extremely marginalized. I felt that what I did in the classroom did not get seen by anyone. It was seen by my students and that's what I'm most concerned about. But everyone, once in a while, you'd like a bit of appreciation for what you do, from your colleagues, from somewhere at your work.

The three themes of becoming aware, becoming unsettled and shifting evoked the image of someone being roused from earlier ways of thinking, and suggested the metaphor of awakening. Further evidence for this metaphor emerged when I examined the participants' two concept maps on effective teaching, which they completed at the beginning and toward the end of the first course. I used the concept maps as a method of triangulating the data. In a commentary on her first concept map, Deana described her initial portrayal of the effective teacher as follows:

The effective teacher is one who knows the subject, who communicates with the students, and who cares about the students. As long as the teacher is well prepared, then the students are supposed to learn. There is no notion of learning strategies [in this map]. Students are expected to absorb the knowledge of the teacher by osmosis. 
The contrast is evident in Deana's commentary on her second map. In her portrayal of the effective teacher, students and their learning processes feature much more prominently:

The effective teacher is able to design a course where objectives are met through student involvement and learning activities.

Deana's first and second concept maps are presented in Figures 1 and 2.

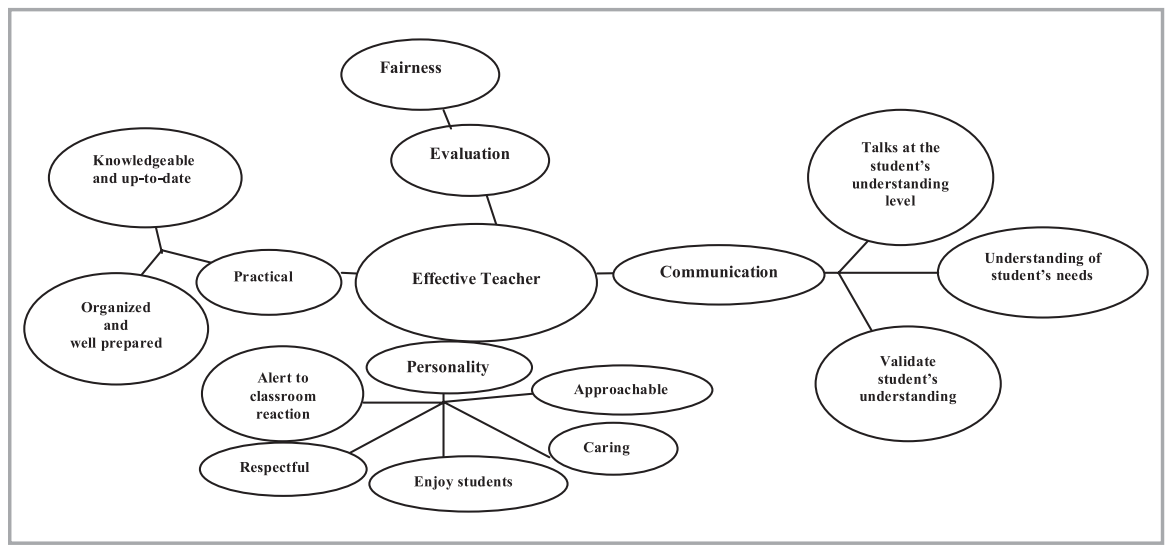

Fig. 1: Deana's first concept map

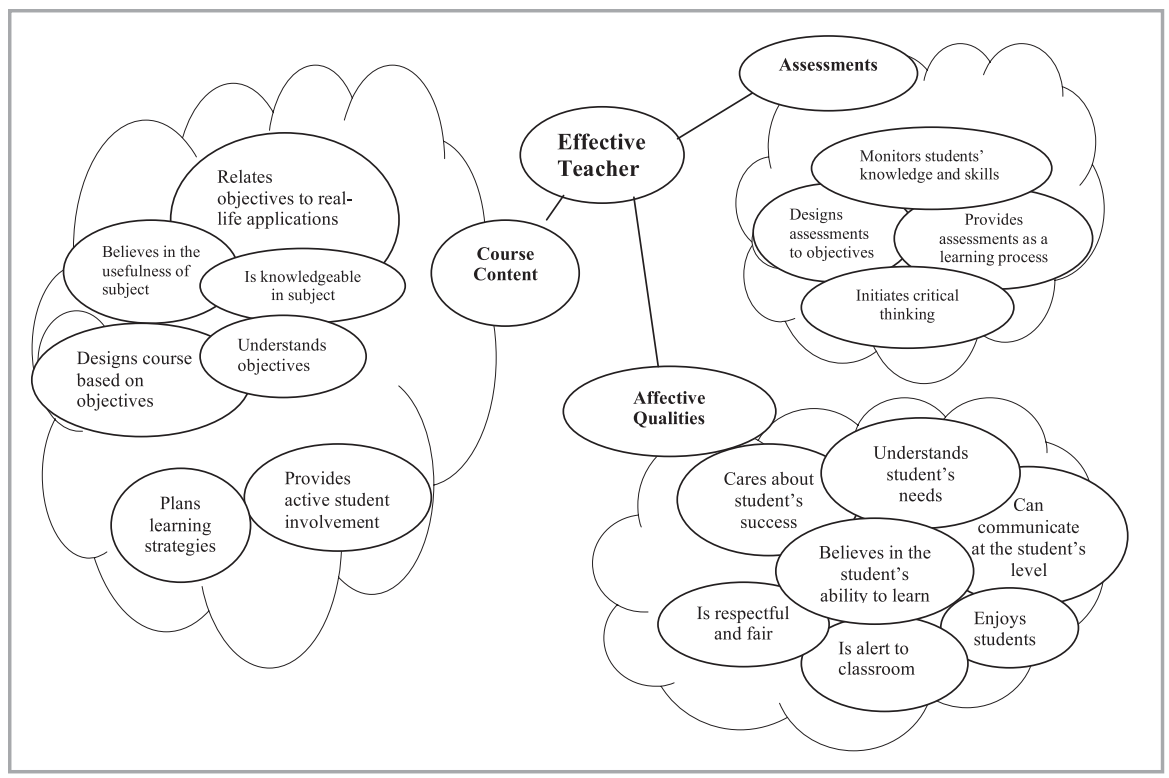

Fig. 2: Deana's second concept map 
During the first set of interviews, the participants expressed enthusiasm for the new ideas they had encountered. However, they were uncertain as to how to integrate these ideas into practice, as revealed in the following excerpt from Anne:

I wasn't really implementing a lot of what I was learning. I think I felt very invigorated and realized there was a lot to learn here and I enjoyed what I was learning, but I wasn't feeling comfortable enough to initiate a lot of new changes in the classroom.

When I met the participants for the second set of interviews, they had completed the second course, Psychology of Learning. Their knowledge of the learner and understanding of the learning process had expanded. Anne summarized the impact this knowledge had on her practice: "I have become more aware of looking at students as individuals and trying to figure out why they are there."

However, several participants regarded the course material as challenging, and they experienced difficulty making cognitive links between theory and practice. Ella expressed this sentiment as follows: "It raised a lot of questions in my mind and I have some answers, but I don't know if I have a lot of the answers. I think the psychology of learning is pretty complex."

I represented this second phase through the metaphor of stretching. Comprehending how a theory can be used as a tool to understand and diagnose issues related to learning proved to be a demanding task for the participants. The reflective journals which they completed throughout the program helped them to make links between theory and practice. In the following excerpt, Deana describes her initial resistance to journal writing, followed by a breakthrough:

At first, I did not want to think about who I was as a teacher. It was just too difficult. After the third or fourth journal I started to recognize their use. I started to connect the readings with my teaching. I was becoming a little more open.

During this phase, the MTP classroom milieu, in which ideas about learning were shared among teachers from various disciplines, was mentioned by several participants as an important component of their learning process.

In general, it was only after the third set of interviews that participants reported feeling confident enough to implement new instructional strategies in their 
classrooms. These findings emerged in the second year of the program. The participants stated that they were moving out of their comfort zone and away from traditional ways of delivering content, as they integrated strategies designed to promote active student involvement. They also demonstrated an enhanced capacity to critically reflect on their practice. If classroom activities did not go as planned, they were able to call upon tools of analysis that enabled them to evaluate the situation, adjust the strategy, and try again. I referred to this phase as exercising, as the participants reportedly made the leap from theory to practice. Their background knowledge on how students learn appeared to be activated, influencing both their preparation and use of class time. Several teachers, including Fran below, mentioned a move away from "covering the content."

The thing that I've learned more than anything else is to not sweat the content quite as much as I used to. Give them the tools to go to the next level; let them be learners and find the joy in it.

Data from the fourth set of interviews showed that participants had reached new insights about the meaning and purpose of assessment. This is illustrated in the following excerpt from Barb's interview: "Back in the old days I would think, I'm teaching, now I have to do an evaluation; what a drag! Now I know that assessment drives the learning. Students learn what they're going to be assessed on."

I would describe the participants' encounter with assessment as the most significant group awakening moment of the study, as they came to view assessment as a benchmark of student learning. This not only impacted their perspectives, but also, according to self-reports, influenced their practice. At this time, in the second year of the program, they demonstrated a more integrated understanding of the roles of teacher, learner, and curriculum. I referred to this phase as shaping.

\section{Connecting the Data}

The four patterns that emerged as a result of coding the interview data also appeared, to greater or lesser extents, in the individual narratives which I constructed, using the participant's own words. This served to confirm further the themes that had emerged. In her narrative which I entitled Becoming Open to Change, Deana, a new teacher, describes her process of learning:

When I look back over the MTP, I would say I've gone through several stages. First I had to learn this new knowledge. Then I had to take ownership for it 
by connecting it to my discipline-I resisted this step. Finally, after careful planning, I tried new strategies.... I felt I was becoming more open to change.

The two other narratives suggest similar patterns, that is, that a change in perspectives on teaching and learning preceded changes in practice. In general, results indicate that it took at least one year before perspectives were sufficiently in place to enable the participants to feel confident enough to implement changes in the classroom. However, Fran, a more experienced teacher, showed earlier signs of implementing changes in her practice, and this finding attests to the importance of including a more contextualized analysis.

The major themes of becoming open to change, learning as a student, and learning in community emerged in the narrative summaries. Anne, who had taught for five years, describes how her experience as a learner in the MTP has caused her to rethink her pedagogy. I entitled her narrative, Learning as a Student:

I've become even more aware of my students as individual learners. I realize I am quite motivated in my studies but I often think about what motivates them. I think the fact that I am a student has helped us to have a more open relationship - they know that I have assignments and deadlines too! I'm realizing even more that assessments have to match learning objectives. I'm wondering whether all those tests and assignments that I give and all that stress is really warranted. Perhaps we can assess more with less. I'm thinking of exploring group work.

The search for community was the driving force that first led Fran, an experienced teacher, to seek professional development. What emerged in her narrative was not only the sense that the program had validated her as an educator, but also that it had helped her to further validate her students and their learning. I entitled her narrative, Learning in Community:

We [teachers] have a lot to teach each other. I need the nourishment that this program provides at this point in my teaching career.... I believe in communities of learners. I didn't know that was my educational philosophy before, but now I do. I believe we are all in this together. Not only am I willing to give my students more information and more transparency, but I invite them to take part to a greater degree. I'm more open to negotiating what gets learned. In the past when I did this I felt I was being subversive, 
and, in some ways, not a "good teacher" in the old, unenlightened sense of the word. All that has changed.

Findings from the dual analytic processes of categorizing and connecting converged to reveal similar results. Evidence showed that the participants' perspectives had shifted from a teacher-centered/content-focused orientation, toward a student-centered/learner-focused orientation. This shift from teacher- to learner- centeredness has been described by other researchers (e.g., Kember, 1997; Kember \& Kwan, 2002; Samuelowicz \& Bain, 2001). Further, my findings provided empirical support for theoretical models such as Robertson (1999). My findings also showed that this shift was marked by three major dimensions: increased awareness of the learner and the learning process, increased intentionality to align the curriculum, and increased self-knowledge.

\section{Three Dimensions}

At the beginning of the program, the participants' initial descriptions of the learner revealed a number of misconceptions, which were often based on their own experiences as learners. As they encountered new information these perspectives altered, from viewing the student as a passive player, to one who learns best when actively engaged in the learning process. As well, there was a notable increase in their awareness of the individuality of student learning styles. Increased knowledge and awareness of the learner and the learning process have been identified as principal components of effective teaching in higher education (Beaty, 1998; Wilson, Shulman, \& Richert, 1987).

A second major dimension concerned the teacher and the teaching process. Initially, the teacher was viewed as the center, and the emphasis was placed on the delivery of content. As perspectives evolved, participants showed evidence of expanded pedagogical knowledge and a more critical outlook on their teaching. There were also signs of increased intentionality as they sought to align the curriculum by matching course objectives, learning tasks, and assessments. Their emphasis was on demystifying the learning process for students and orchestrating specific learning outcomes. Ella describes this change as follows: "The clarity [in my teaching] has improved and students need that. They don't need the data dump. They have access to information. They just need focus." 
The third dimension, knowledge of self, is defined by Grossman (1995) as an awareness of one's values, strengths, weaknesses, and pedagogical goals. It has also been identified as a key component in successful teaching. As the participants became more aware of what was transpiring in the classroom, they reached new insights about themselves as educators. They reported an increased enjoyment in their teaching and an enhanced feeling of confidence. This confidence was manifested in their sense of themselves as teacher professionals. Anne describes this as follows: "I'm much more confident in the classroom. I speak from a position of knowledge of teaching, as opposed to just my discipline."

In spite of some of the challenges that participants had referred to throughout the program, such as balancing teaching responsibilities with their studies, an important outcome of the MTP appears to be an enhanced sense of identity as a teacher professional. The participants had shifted from viewing themselves uniquely as masters of their discipline, to viewing themselves as master teachers of their discipline. This suggests that knowledge of self as a teacher professional is a critical element of self-knowledge and of successful professional development programs. Grossman's definition of self-knowledge cited above should be expanded to include this component.

\section{Reflection on Practice}

Reflection on practice over time emerged as the major mechanism underlying changes in perspectives on teaching and learning. The process of reflecting, which was assessed through interview data, journal entries, and concept maps, helped the participants link theory with practice. It provided them with tools to deconstruct what was happening in their classrooms, a process that Schön (1987) has described as "thinking on your feet." Anne describes how the process of reflection has afforded her critical insight into her practice: "The MTP has taught me to take the time to reflect. If you don't reflect, you're not going to change. And what you're offering the students isn't going to change either."

Journal writing served as an important medium for Fran's reflections:

It's the process of writing that does the teaching. It helps you shape those ideas. I feel that I am embarking on a career as a connoisseur and it changes things entirely. I see with new eyes, sometimes things I have seen for years, and not really seen. 
Through reflection, participants reported that they were better equipped to examine the learning environment, assess the situation, and adjust their practice accordingly. Furthermore, as their knowledge base increased, their reflections became increasingly grounded in theory.

\section{Discussion and Limitations}

The importance of examining teachers' perspectives was underscored in this study. New teachers, in particular, often hold misconceptions about teaching and learning that exert a negative influence on their practice. In order to improve the quality of teaching in higher education, these perspectives must first be addressed (McAlpine \& Weston, 2000). The discourse on teacher perspectives offers an opportunity for radical change (Goodyear \& Hativa, 2002). Professional development programs such as the MTP that address these perspectives represent a productive way forward.

Findings from this study detail the process of evolution in perspectives among teachers in higher education. In particular, these findings provide empirical support for the evolution in perspectives that has occurred among CEGEP teachers involved in the MTP. This evolution was demonstrated through the four patterns of awakening, stretching, exercising, and shaping. Additional signs of evolution as teacher practitioners were evident through increased awareness of the learner, greater intentionality in teaching, and enhanced self-knowledge. Moreover, the four patterns revealed that changes in the participants' perspectives preceded changes in their classroom practice, confirming one of the basic assumptions the MTP is based upon (see Bateman, 2002). In both describing a process of evolution from a teacherto a learner-centered perspective through four patterns and three dimensions, and in specifying a time period of one year before perspectives impacted significantly on practice, this study answers the research question posed, and in doing so it contributes to the literature. This study is also unique in terms of its methodology, in that both categorizing and connecting procedures were used, with each procedure providing a unique analytic lens onto the data. For example, although evidence for the four patterns emerged through both procedures, some contextualized differences with respect to the time frame became apparent in the narrative summaries. Novice teachers seemed to adhere to the four patterns and time frame more closely than the experienced teacher. Both experience and disciplinary background may influence the rate of progression through the four patterns. Further research is required to clarify this. 
Teacher professional identity emerged as an important component of selfknowledge in this study. The participants' identity as disciplinary experts expanded to include that of pedagogic expert. To this end, several participants mentioned the importance of engaging in professional dialogue with colleagues. They also stated that, aside from programs such as the MTP, few opportunities exist for teachers at the CEGEP level to become involved in this type of exchange. These findings suggest that more spaces need to be created to encourage a sense of teacher professional identity. In order to promote teaching excellence, institutions of higher education must be prepared to invest in this process. Finding additional ways to support and reward teacher participation in professional development programs such as the MTP are crucial.

This study has a number of limitations. Although the six participants represent a purposive sample, including male voices as well as teachers from all of the CEGEPs involved in the MTP would result in even greater representation. While I mention peer support as an important component of successful professional development programs, the time and scope of this study did not permit me to explore this factor more fully. Another limitation of this study is that I was unable to corroborate participants' self-reports with evidence from their teaching practice. In a follow-up study, I would examine a recording each teacher makes of her teaching in the second year of the program. This would allow me to explore the link between what teachers say they do (espoused beliefs) and their practice (theories-in-use) (Argyris \& Schön, 1974; Kane, Sandretto, \& Heath, 2002).

Learning to teach in higher education has emerged as a complex process that evolves over time. The results of this study further challenge the assumption of double professionalism, that is, that disciplinary expertise entails a capacity to teach effectively (Beaty, 1998). I am grateful to my six participants for sharing their perspectives on teaching and learning with me. Their insights and reflections have provided me with much food for thought, and have helped to inform my evolving practice.

\section{Notes}

1. This study was conducted in partial fulfillment of the requirements for a doctoral degree in Education at McGill University. The PAREA grant that I received through the Ministry of Education of the province of Quebec, Canada, during the 20072008 academic year, enabled me to complete the study. 


\section{References}

Argyris, C., \& Schön, D. (1974). Theory in practice: Increasing professional effectiveness. San Francisco: Jossey-Bass.

Bateman, D. (2002, July). Passing the torch: Designing a professional development program for new CEGEP teachers. Pédagogie Collégiale, 14(3), 8pp. Retrieved July 27, 2004, from http://www.aqpc. qc.ca/revue/en/pc_v14n3_01/art02.html.

Beaty, L. (1998, May). The professional development of teachers in higher education: Structures, methods and responsibilities. Innovations in Education and Training International, 35(2), 99-107.

Boyer, E. (1987). College: The undergraduate experience in America. New York: Harper \& Row.

Bransford, J., Brown, A., Cocking, R., \& Donovan, S. (Eds.) (2000). How people learn: Bridging research and practice. Washington, DC: National Academy Press.

Brew, A. (1999). Research and teaching: Changing relationships in a changing context. Studies in Higher Education, 23(3), 291-301.

Charmaz, K. (1998). The grounded theory method: An explication and interpretation. In R. Emerson (Ed.), Contemporary field research: A collection of readings ( $p p$. 109-126). Prospect Heights, IL: Waveland.

Charmaz, K. (2000). Grounded theory: Objectivist and constructionist methods. In N. Denzin \& Y. Lincoln (Eds.), Handbook of qualitative research (pp. 509-535). Thousand Oaks, CA: Sage.

Charmaz, K. (2005). Grounded theory in the $21^{\text {st }}$ century. In N. Denzin \& Y. Lincoln (Eds.), Handbook of qualitative research (pp. 507-535). Thousand Oaks, CA: Sage.

Fang, Z. (1996). A review of research on teacher beliefs and practices. Educational Research, 38(1), 47-65.

Goodyear, P., \& Hativa, N. (2002). Introduction: Research on teacher thinking, beliefs and knowledge in higher education. In N. Hativa \& P. Goodyear (Eds.), Teacher thinking, beliefs and knowledge in higher education (pp. 1-13). Boston: Kluwer Academic Publishers.
Grossman, P. (1995). Teachers' knowledge. In T. Anderson (Ed.), The international encyclopedia of teaching and teacher education (pp. 20-24). Oxford, UK: Pergamon.

Hativa, N. (2002). Becoming a better teacher: A case of changing the pedagogical knowledge and beliefs of law professors. In N. Hativa \& P. Goodyear (Eds.), Teacher thinking, beliefs and knowledge in higher education (pp. 289-319). Boston: Kluwer Academic Publishers.

Kane, R., Sandretto, S., \& Heath, C. (2002). Telling half the story: A critical review of research on the teaching beliefs and practices of university academics. Review of Educational Research, 72(2), 177-228.

Kember, D. (1997). A reconceptualization of the research into university academics' conceptions of teaching. Learning and Instruction, 7(3), 255-275.

Kember, D., \& Kwan, K. (2002). Lecturers' approaches to teaching and their relationship to conceptions of good teaching. In N. Hativa \& P. Goodyear (Eds.), Teacher thinking, beliefs and knowledge in higher education (pp. 219-239). Boston: Kluwer Academic Publishers.

Knapper, C. (2005). Teaching and learning in Canada's research universities. Keynote address presented at the Canadian Summit on the Integration of Teaching and Research, University of Alberta, Canada.

Lakoff, G., \& Johnson, M. (2003). Metaphors we live by. Chicago: University of Chicago Press.

Lieblich, A. (1998). Reading a life story from a holistic-content perspective. In A. Lieblich, R. Tuval-Mashiach, \& T. Zilber (Eds.), Narrative research: Reading, analysis and interpretation (pp. 62-87). Thousand Oaks, CA: Sage.

Maxwell, J., \& Miller, B. (2008). Categorizing and connecting strategies in qualitative data analysis. In P. Leavy \& S. Hesse-Biber (Eds.), Handbook of emergent methods (pp. 461-477). New York: Guilford Press. 
Maykut, P., \& Morehouse, R. (1994). Beginning qualitative research: $A$ philosophic and practical guide. New York: Falmer Press.

McAlpine, L., \& Weston, C. (2000). Reflection: Issues related to improving professors' teaching and students' learning. Instructional Science, 28, 363-385.

Mezirow, J. (1981). A critical theory of adult learning and education. Adult Education, 32(1), 3-24.

Mezirow, J. (1992). Transformative dimensions of adult learning. San Francisco: Jossey-Bass.

Nicholls, G. (2001). Professional development in higher education. London: Kogan Press.

Ramsden, P. (1992). Learning to teach in higher education. London: Routledge.

Rhodes, C. (2000). Ghostwriting research: Positioning the researcher in the interview text. Qualitative Inquiry, 6(4), 511-525.

Robertson, D. (1999). Professors' perspectives on their teaching: A new construct and developmental model. Innovative Higher Education, 23(4), 271-294.

Samuelowicz, K., \& Bain, J. (2001). Revisiting academics' beliefs about teaching and learning. Higher Education, 41, 299-325.
Saroyan, A., \& Amundsen, C. (2004) (Eds.). Rethinking teaching in higher education. Virginia: Stylus Publishing.

Saroyan, A., Amusden, C., McAlpine, L., Weston, C., Winer, L., \& Gandell, T. (2004). Assumptions underlying workshop activities. In A. Saroyan \& C. Amundsen (Eds.), Rethinking teaching in higher education (pp. 15-32). Virginia: Stylus Publishing.

Schön, D. (1987). Educating the reflective practitioner. San Francisco: Jossey-Bass.

Seidman, I. (1998). Interviewing as qualitative research (2 ${ }^{\text {nd }}$ ed.). New York: Teachers College Press.

Sprinthall, N., Reiman, A., \& Thies-Sprinthall, L. (1996). Teacher professional development. In J. Sihula (Ed.), Handbook of research on teacher education (pp.666-703). New York: Macmillan.

Wilson, S., Shulman, L., \& Richert, A. (1987). 150 different ways of knowing: Representations of knowledge in teaching. In J. Calderhead (Ed.), Exploring teachers' thinking (pp. 104-124). London: Cassell.

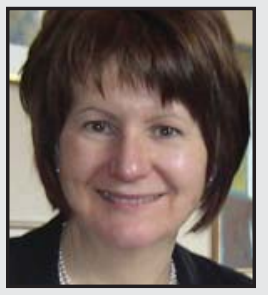

Susan Kerwin-Boudreau is a dedicated college teacher with a unique combination of theoretical and practical knowledge in psychology and methodology. She has thirty-five years of college teaching experience, including work with atrisk and gifted students. Her research background includes both quantitative and qualitative methods. She has coordinated various team research projects. Her doctoral studies in Education focused on teacher professional development in higher education. Her thesis is scheduled to be published in 2009 by Edwin Mellen Press. 